Some Results of

Geochemical Sampling

in McCormick County,

South Carolina

GEOLOGICAL SURVEY BULLETIN 1376

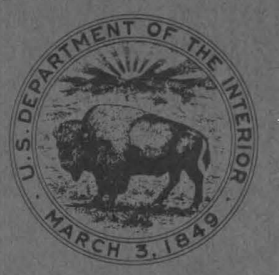





\section{Some Results of}

Geochemical Sampling

in McCormick County,

South Carolina

By HENRY BELL III

G E O L O G I A L S UR VEY B ULLE T I N 1376

Stream alluvium, saprolite, and rock were used to evaluate statistically areas

favorable for prospecting in the

Carolina slate belt

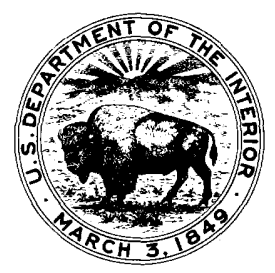




\section{UNITED STATES DEPARTMENT OF THE INTERIOR}

ROGERS C. B. MORTON, Secretary

\section{GEOLOGICAL SURVEY}

V. E. McKelvey, Director

Library of Congress catalog-card No. 73-600109

For sale by the Superintendent of Documents, U.S. Government Printing Office Washington, D.C. 20402 - Price $\$ 1.75$ domestic postpaid or $\$ 1.50$ GPO Bookstore Stock Number 2401-00334 


\title{
CONTENTS
}

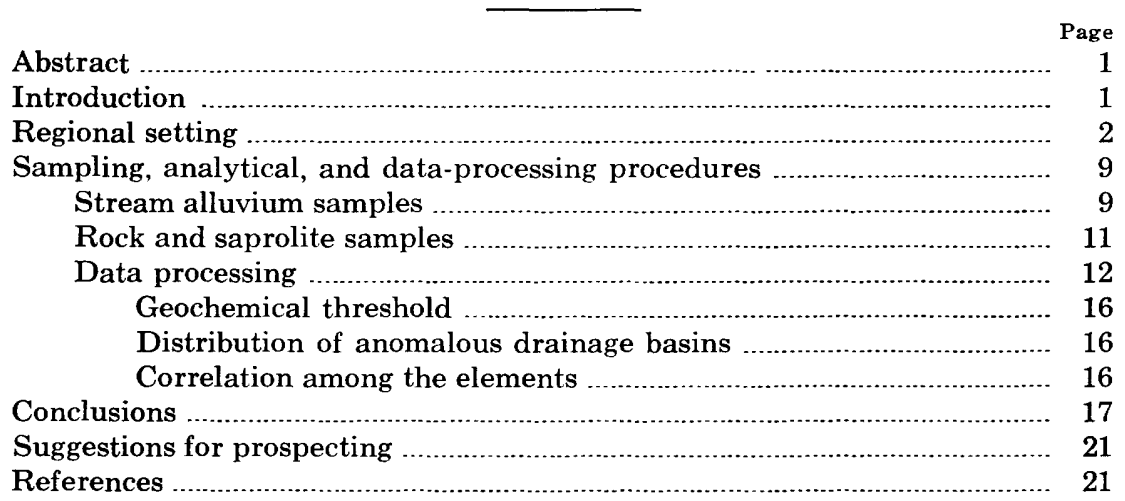

\section{ILLUSTRATIONS}

\author{
[Plates are in pocket]
}

Plates 1-5. Maps showing small-stream drainage basins:

1. In which fine alluvium contains threshold or greater amounts of an element, McCormick area, South Carolina.

2. In which heavy-mineral concentrates contain one or more gold particles identified in the gold pan, or $>20$ parts per million determined by spectrographic analysis, McCormick area, South Carolina.

3. In which heavy-mineral concentrates contain a magnetic fraction $\geq 4.8$ grams, McCormick area, South Carolina.

4. In which the nonmagnetic fraction of heavy-mineral concentrates contains threshold or greater amounts of an element determined by spectrographic analysis, McCormick area, South Carolina.

5. That provide the most favorable indication of underlying gold-, copper-, zinc-, lead-, and manganese-bearing rock, McCormick area, South Càrolina.

Figure 1. Index map showing some geologic features in South

Page

Carolina and Georgia

2. Photographs of characteristic rocks of McCormick County ...........

3. Map showing conspicuously alined stream segments indicating fault, joint, bedding, or cleavage direction in parts of

McCormick and Edgefield Counties, S.C., and

Lincoln County, Ga 
Figure4. Reconnaissance geologic map of the McCormick and Plum Branch quadrangles showing small-stream

drainage basins

5. Map showing location of saprolite- and soil-sampling traverses and mineralized zones and their probable extensions near the Jennings mine, McCormick County, S.C .. 13

6. Diagram showing distribution of anomalous metal values in samples from road traverses shown in figure 5

7. Idealized ground plan of the veins at the Dorn mine

8. Diagram showing Kendall's correlation coefficients for analyses of felsic fragmental rocks and greenstone in drill core from the Jennings mine area

\section{TABLES}

TABLE 1. Chemical analyses of some rocks from McCormick County,

S.C., and Lincoln County, Ga

2. Summary of colorimetric and atomic absorption analyses of fine alluvium from small streams, McCormick County, S.C

3. Summary of spectrographic analyses of 59 fine alluvium samples from small streams, McCormick County, S.C

4. Summary of spectrographic analyses of 56 heavy-mineral concentrates from small streams, McCormick County, S.C

5. Summary of spectrographic analyses of saprolite and drill core from the vicinity of the Jennings mine, McCormick County, S.C

6. Kendall's correlation coefficients for drill core analyses in the Jennings mine area, McCormick County, S.C 


\title{
SOME RESULTS OF GEOCHEMICAL SAMPLING IN McCORMICK COUNTY, SOUTH CAROLINA
}

\author{
By Henry BeLL III
}

\section{ABSTRACT}

Geochemical samples of stream alluvium in McCormick County, S.C., supplemented by samples of saprolite and rock in the vicinity of the Jennings and Dorn mines, indicate a north-trending zone of stream basins containing alluvium anomalously rich in copper, lead, zinc, manganese, and gold. This zone of anomalous stream basins lies along possible faults which cut the extensions of the mining areas at a high angle, suggesting a new northward direction in which prospecting may be most fruitful.

Kendall's correlation coefficients computed from analyses of drill core obtained near the mining area were used to evaluate the stream basins for anomalous metal content.

\section{INTRODUCTION}

The Dorn mine is the most famous of a group of old gold mines in McCormick County, S.C., which produced gold between 1852 and 1880 from shallow workings. In the 1930's deeper workings along the trend of the old mines encountered complex sulfide ore containing galena, sphalerite, and chalcopyrite with generally unprofitable values in gold. Supergene manganese minerals, probably derived from rhodonite or rhodocrosite, are also common in places and were mined from one of the pits along the Dorn trend. In spite of the fact that the mineralized area has been known for many years, the geologic setting and the extent of mineralized ground around the mines are poorly known. Investigations for heavy metals in the Southeastern United States afforded an opportunity to relate the mineralized ground to regional geologic features and to test by reconnaissance sampling whether the complex sulfide ores are widespread.

The sampling was accomplished with the aid of Henry S. Johnson, Jr., and Vernon Geyer of the South Carolina State Development Board, Geologic Division. Samples of diamond drill core were kindly provided by the Tennessee Copper Co. Mr. Jennings Dorn of McCormick kindly cooperated in the project and provided information about mining properties in the area.

Reconnaissance geologic mapping begun by Henry S. Johnson, Jr., South Carolina State Geologist, was continued, and stream sediments were sampled. Supplementary data were obtained from samples of 
rocks and saprolite cropping out along roads and in prospect pits. The samples were collected from an area centering on the town of McCormick.

\section{REGIONAL SETTING}

The area (fig. 1) is underlain by rocks of the Carolina slate belt (Overstreet and Bell, 1965a, and b) known across the Savannah River in Georgia as the Little River Series of Peyton and Cofer (1950). McCormick is close to the area where these low-grade regionally metamorphosed rocks pass into higher grade rocks associated with the Charlotte belt. The slate belt rocks near McCormick are characteristically steeply dipping fragmental volcanic rocks, largely felsic but with interlayered mafic units and greenstones. Figure 2 shows some characteristic rock types from McCormick County. Farther south in the county are thinly bedded, gently folded sedimentary rocks with a low dip to the southeast. A large part of these are argillites (fig. $2 C$ ) similar to the Tillery Formation, widespread in the North Carolina portion of the Carolina slate belt. Near McCormick and extending southwestward to near Lincolnton, Ga., is a mass of leucocratic phaneritic granitoid metadacite (fig. 2D) (Crawford and others, 1966) composed essentially of oligoclase $\left(\mathrm{An}_{21}\right)$ and quartz. Large bluish quartz grains give a subporphyritic texture (Fouts, 1966). Locally a chilled phase has a fine-grained matrix and bluish quartz phenocrysts. The rock is cut by many dikes locally. Table 1 gives some chemical analyses of these rocks. Coarse fragmental felsic volcanic rocks apparently surround the metadacite conformably, and many have abundant coarse bluish quartz grains very similar to those in the metadacite. The amount of bluish quartz in the felsic fragmental rocks diminishes to the south away from the metadacite. The fragmental rocks with bluish quartz grains may be volcanic ejecta derived from the metadacite, which was a shallow instrusive or volcanic dome. The Dorn mine, the Jennings mine, and the Searle mine are in altered fragmental volcanic rocks close to the eastern limit of this metadacite mass (fig. 1). Similarly, the Seminole-Magruder mine, a gold and copper producer in rocks of the Little River Series with mineralogy similar to the Dorn mine; is near the western limit of this metadacite in Georgia. Northeast of McCormick, and close to the metadacite, is a coarse-grained gabbro, which is circular in plan and bordered by a contact metamorphic aureole extending nearly to McCormick. In hand specimen the gabbro resembles the gabbro in the string of plutons which cut rocks of the Charlotte belt and Carolina slate belt from Georgia to North Carolina. Some greenstones interbedded with felsic rocks are fragmental, but others may be flows (fig. $2 B$ ). South of the metadacite, many of the finer grained felsic rocks are hydrothermally altered to quartz-sericite schist and quartz- 


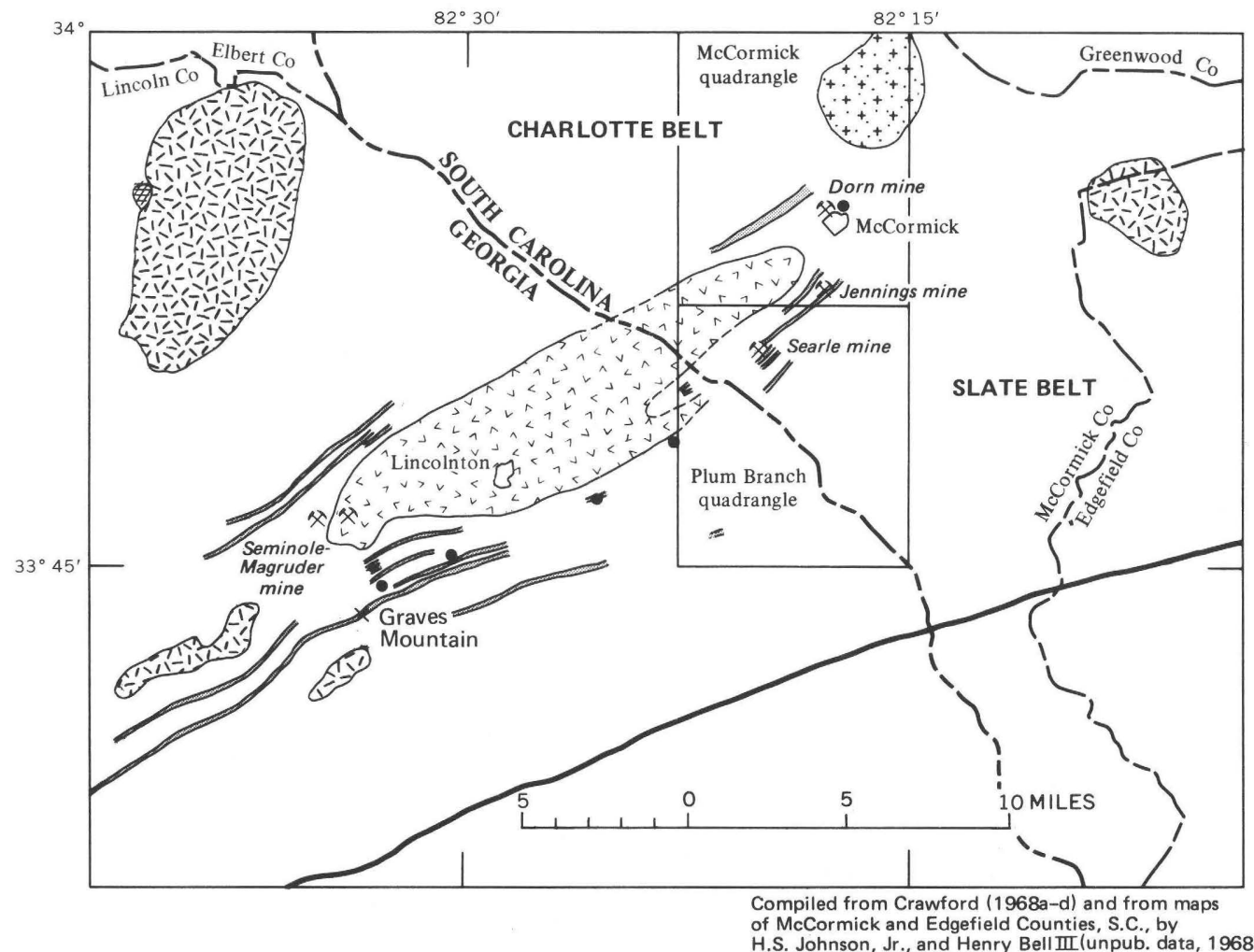

\section{EXPLANATION}

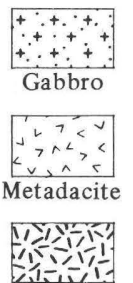

Granite, undifferentiated

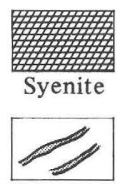

Quartz-sericite schist in Georgia and greenstone in South Carolina

$$
\begin{gathered}
\frac{\text { Contact }}{\text { Major fault }} \\
\text { Mine } \\
\text { Manganese deposit }
\end{gathered}
$$

FIGURE 1.-Index map showing some geologic features in South Carolina and Georgia, and location of the McCormick and Plum Branch quadrangles. 


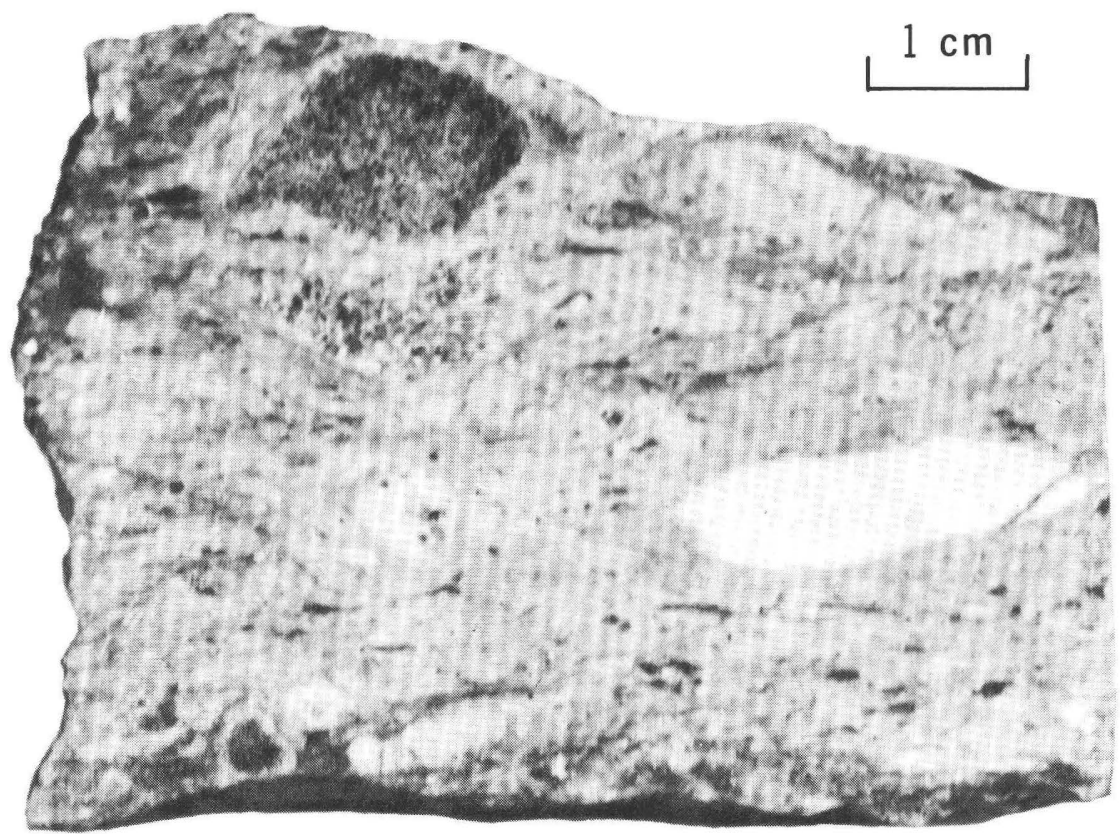

$A$

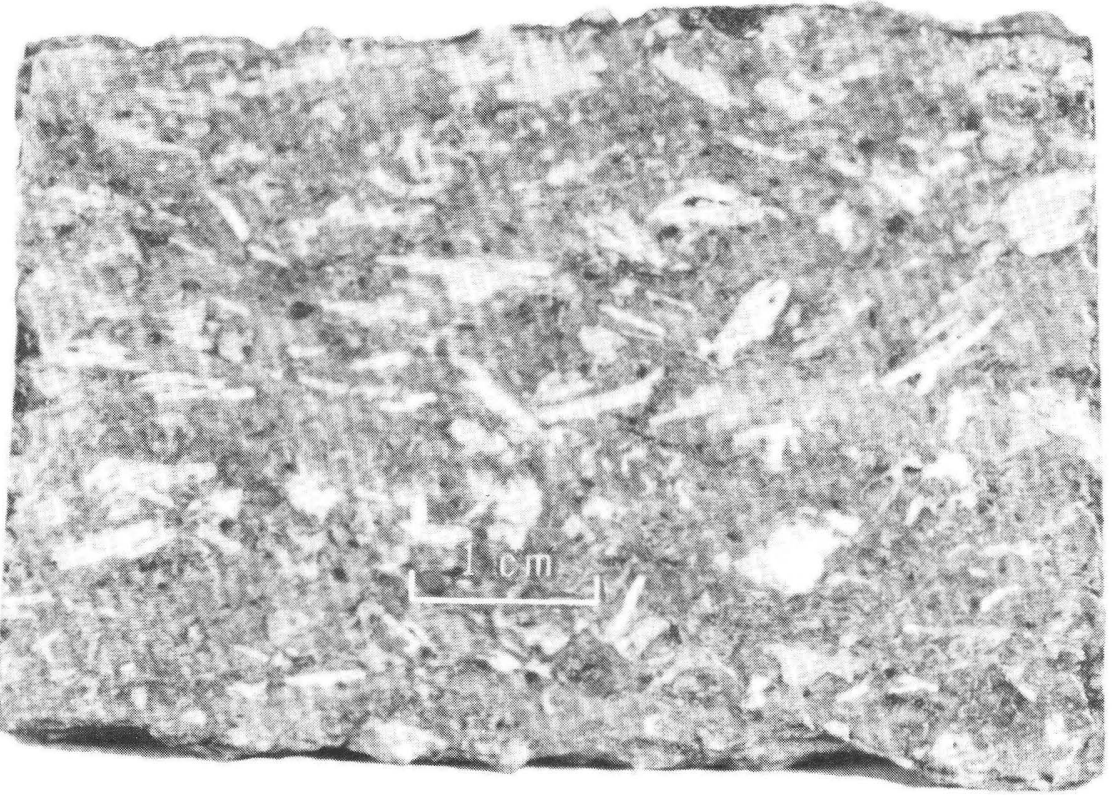




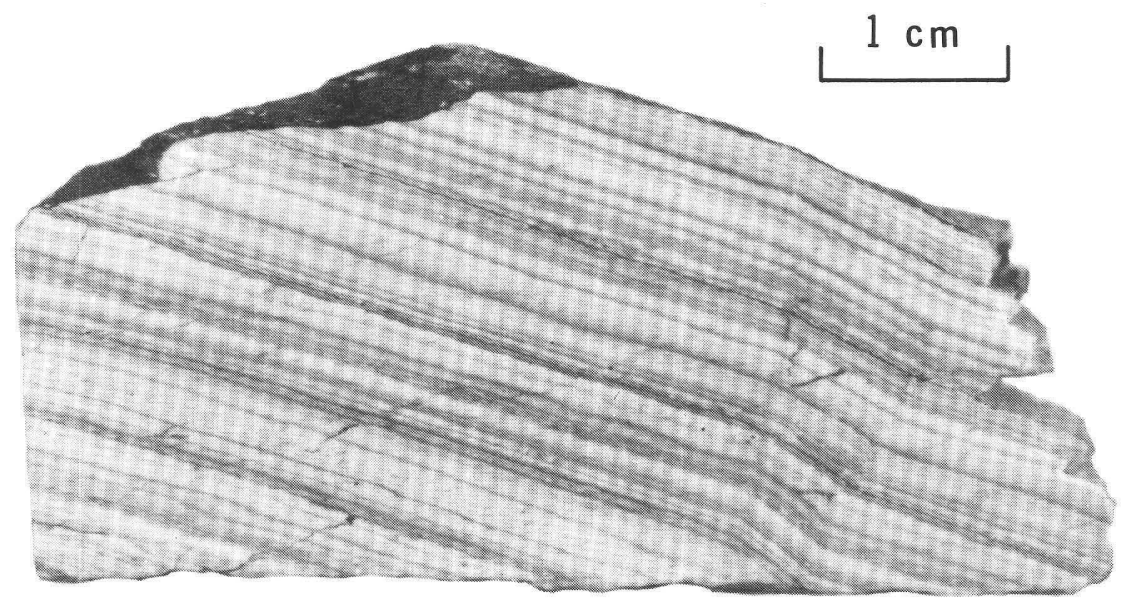

$C$

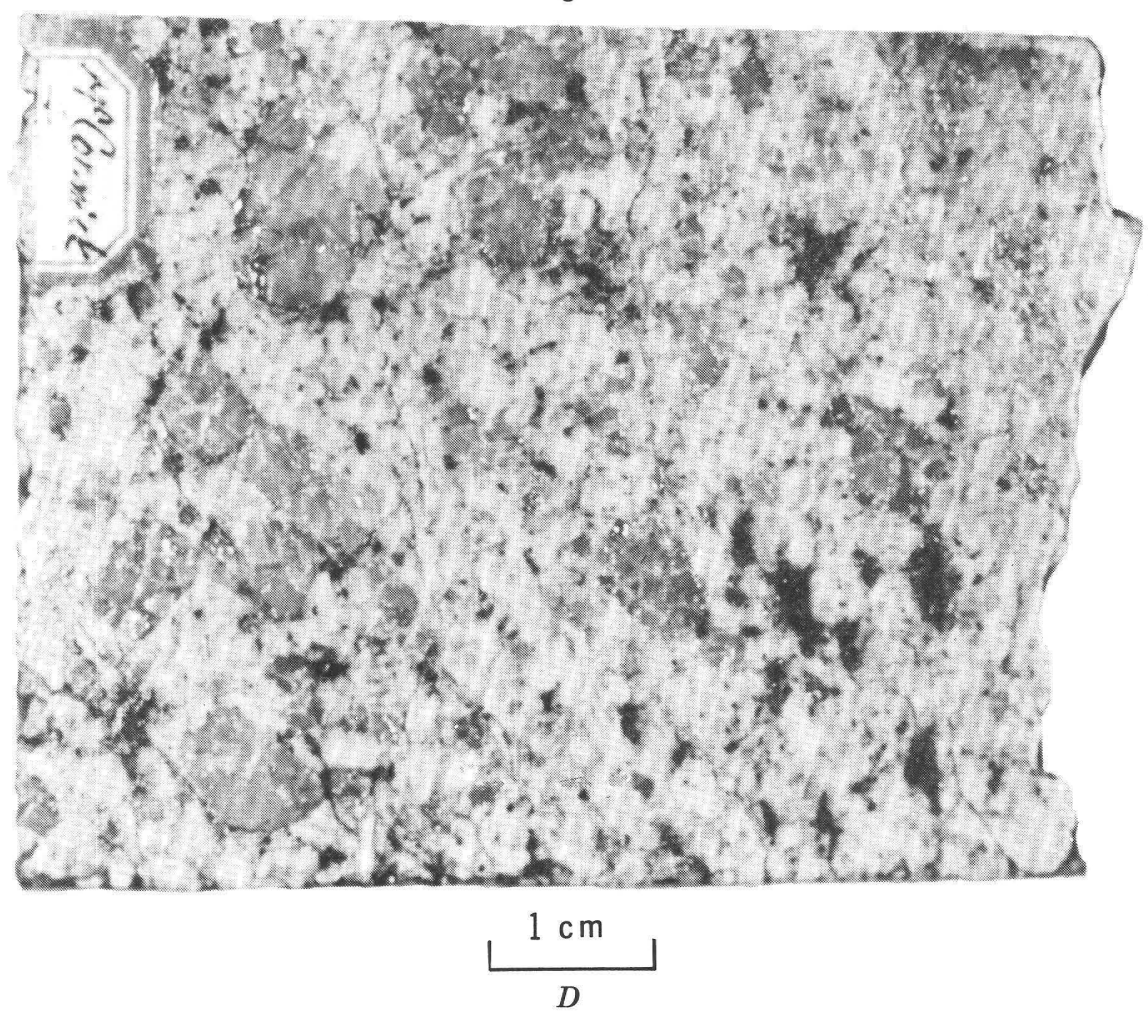

Figure 2.-Characteristic rocks of McCormick County, S.C. A, Fragmental volcanic rock from near McCormick; $B$, Porphyritic greenstone from shore of Clark Hill Reservoir at the mouth of Plum Branch; $C$, Laminated argillite from southern McCormick County; $D$, metadacite from near McCormick. Photographs of sawed surfaces by Carl Ealy, U.S. Geological Survey. 
TABLE 1.-Chemical analyses of some rocks from McCormick County, S. C., and Lincoln County, Ga.

\begin{tabular}{|c|c|c|c|c|}
\hline & 1 & 2 & 3 & 4 \\
\hline \multicolumn{5}{|c|}{ Major oxides ${ }^{1}$ (weight percent) } \\
\hline $\begin{array}{l}\mathrm{SiO}_{2} \\
\mathrm{Al}_{2} \mathrm{O}_{3} \\
\mathrm{Fe}_{2} \mathrm{O}_{3} \\
\mathrm{FeO} \\
\mathrm{MgO} \\
\mathrm{CaO}\end{array}$ & $\begin{array}{c}76.2 \\
13.4 \\
.62 \\
.93 \\
.91 \\
.47 \\
5.4 \\
.24 \\
.06 \\
1.3 \\
.34 \\
.05 \\
.07 \\
<.05\end{array}$ & $\begin{array}{c}75.4 \\
11.5 \\
1.8 \\
1.0 \\
2.3 \\
.86 \\
1.75 \\
1.76 \\
.04 \\
2.1 \\
.46 \\
.06 \\
.08 \\
<.05\end{array}$ & $\begin{array}{c}45.6 \\
18.4 \\
4.6 \\
7.4 \\
5.8 \\
7.9 \\
1.8 \\
.36 \\
.10 \\
4.7 \\
1.3 \\
.25 \\
.20 \\
<2.0\end{array}$ & $\begin{array}{r}44.8 \\
14.3 \\
3.5 \\
6.8 \\
17.9 \\
7.9 \\
1.2 \\
.07 \\
.45 \\
2.2 \\
.38 \\
.06 \\
.17 \\
<.05\end{array}$ \\
\hline
\end{tabular}

Semiquantitative spectrographic analyses (range, in parts per million) ${ }^{2}$

\begin{tabular}{|c|c|c|c|c|}
\hline $\mathbf{A g}$ & 0 & $0-5$ & 0 & 0 \\
\hline $\mathbf{B a}$ & $100-500$ & $200-1,500$ & $7-1,500$ & $30-100$ \\
\hline $\mathrm{Be}$ & 0 & $0-1.5$ & 0 & 0 \\
\hline Co & 0 & $3-30$ & 30 & $70-100$ \\
\hline $\mathrm{Cr}$ & 0 & $0-30$ & $0-70$ & $150-1,000$ \\
\hline $\mathrm{Cu}$ & 15 & $15-1,000$ & $30-300$ & $10-30$ \\
\hline $\mathrm{Ga}$ & 5 & $5-7$ & $10-15$ & 0 \\
\hline Mo & 0 & $0-20$ & $3-5$ & $0-5$ \\
\hline $\mathrm{Ni}$ & 0 & $0-10$ & $20-70$ & $300-700$ \\
\hline $\mathrm{Pb}$ & $15-100$ & $7-20$ & $15-30$ & 0 \\
\hline Sc & $7-10$ & $5-15$ & $20-30$ & $5-30$ \\
\hline Sr & $20-70$ & $7-200$ & $100-1,000$ & $300-500$ \\
\hline V & 20 & $10-30$ & $100-200$ & $20-200$ \\
\hline$Y$ & $20-30$ & $15-30$ & $15-20$ & 0 \\
\hline Yb & $2-3$ & 0 & $1.5-2$ & 0 \\
\hline Zn & 0 & $0-700$ & 0 & 0 \\
\hline $\mathrm{Zr}$ & 100 & $70-100$ & $15-70$ & $3-30$ \\
\hline
\end{tabular}

1. Metadacite; average of two specimens from Lincoln County, Ga.

2. Felsic fragmental volcanic rocks; average of six specimens of drill core from near the Jennings mine, McCormick County, S. C.

3. Greenstones; average of three specimens of drill core from near the Jennings mine, McCormick County, S. C.

4. Grabbo; average of three specimens, McCormick County, S. C.

${ }^{1}$ Rapid rock analyses using methods described by Shapiro and Brannock (1962) supplemented by atomic absorption. Analysts: Paul Elmore, Lowell Artis, J. Kelsey, Gillison Chloe, H. Smith, S. Botts, and John Glenn.

${ }^{2}$ Results are reported to the nearest number in the series $1,0.7,0.5,0.3,0.2,0.15$, and 0.1 , etc., which represent approximate midpoints of interval data on a geometric scale. O, looked for but not detected. Elements looked for but not detected: $\mathrm{As}, \mathrm{Au}, \mathrm{B}, \mathrm{Bi}, \mathrm{Cd}, \mathrm{Ce}, \mathrm{Eu}, \mathrm{Ge}, \mathrm{Hf}$, $\mathrm{Hg}$, In, La, Li, Nb, Pd, Pt, Re, Sb, Sn, Ta, Te, Th, U, and W. Analysts: W. B. Crandell and J. L. Harris.

sericite-chlorite schist. Pardee and Park (1948, p. 119) reported that in the Dorn mine sulfide minerals "replace the chloritic schist selectively." Graves Mountain near the western end of the metadacite is underlain mainly by quartz-sericite schist, sericite-kyanite-quartz rock and quartz conglomerate (Hurst, 1959). Kyanite is abundant enough to mine; other noteworthy minerals are pyrophyllite, rutile, lazulite, barite, hematite, and pyrite. Espenshade and Potter (1960) consider the Graves Mountain deposits to have the characteristics of a hydrothermal replacement body. A belt of small manganese deposits extends from near the Dorn mine southwestward past Graves Mountain (Hurst and others, 1966). Most of the manganese deposits are surficial accumulations of oxide-rich float, but at one location rhodonite and rhodocrosite are reported, suggesting a probable epigenetic source for some the manganese. 
Many of the topographic maps of McCormick County and adjacent areas show a conspicuous orientation of streams; this orientation is probably controlled by faults, joints, bedding, or cleavage (fig. 3). Most of these alinements trend either northeast or northwest and form an intersecting set. A few conspicuous alinements are markedly divergent and may reflect fractures or faults perhaps of a different age or origin.

The rocks in the area are deeply weathered, and, in general, outcrops are confined to the beds of streams, the shores of the Clarks Hill Reservoir, and artificial cuts. A residuum of rock weathered in place, called saprolite, which retains vestiges of the original minerals, fabric, and structure, is common. Rocks rich in plagioclase feldspar and ferromagnesian minerals are particularly susceptible to weathering and tend to underlie low areas. Quartz-rich rocks and quartz-sericite schists, however, are relatively resistant to weathering and tend to crop out along ridges. In the Dorn mine, oxidized ore is reported to extend to a depth of 50 or 60 feet (Pardee and Park, 1948, p. 119). Small streams are abundant and provide many closely spaced

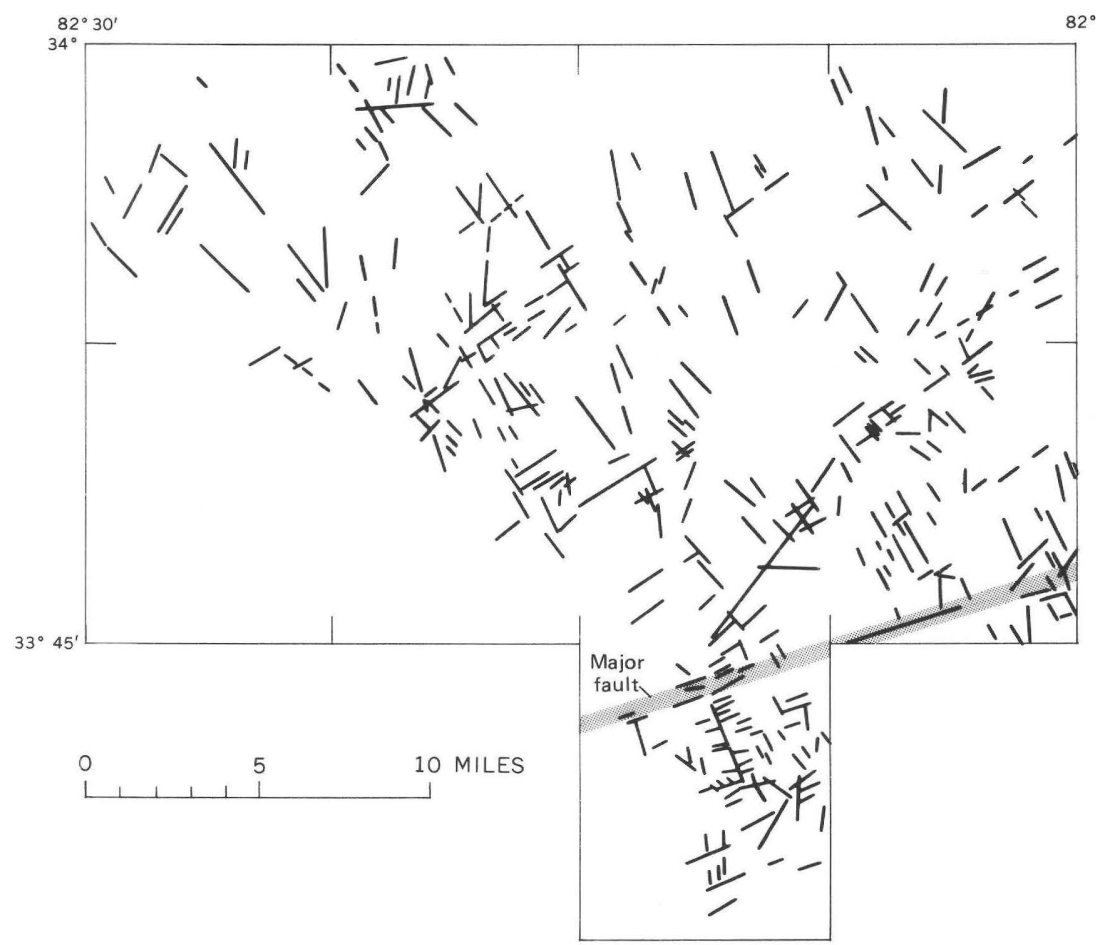

FIGURE 3.-Conspicuously alined stream segments indicating fault, joint, bedding, or cleavage direction in parts of McCormick and Edgefield Counties, S.C., and Lincoln County, Ga. 
sampling sites. These sampling sites, together with an outline of the stream drainage basins upstream from the sample sites, are superimposed on a reconnaissance geologic map (fig. 4) of parts of the McCormick and Plum Branch quadrangles. The lines separating drainage basins are drawn along the divides that separate adjacent drainage basins. Figure 4 shows that most of the small streams drain areas underlain by several rock types.

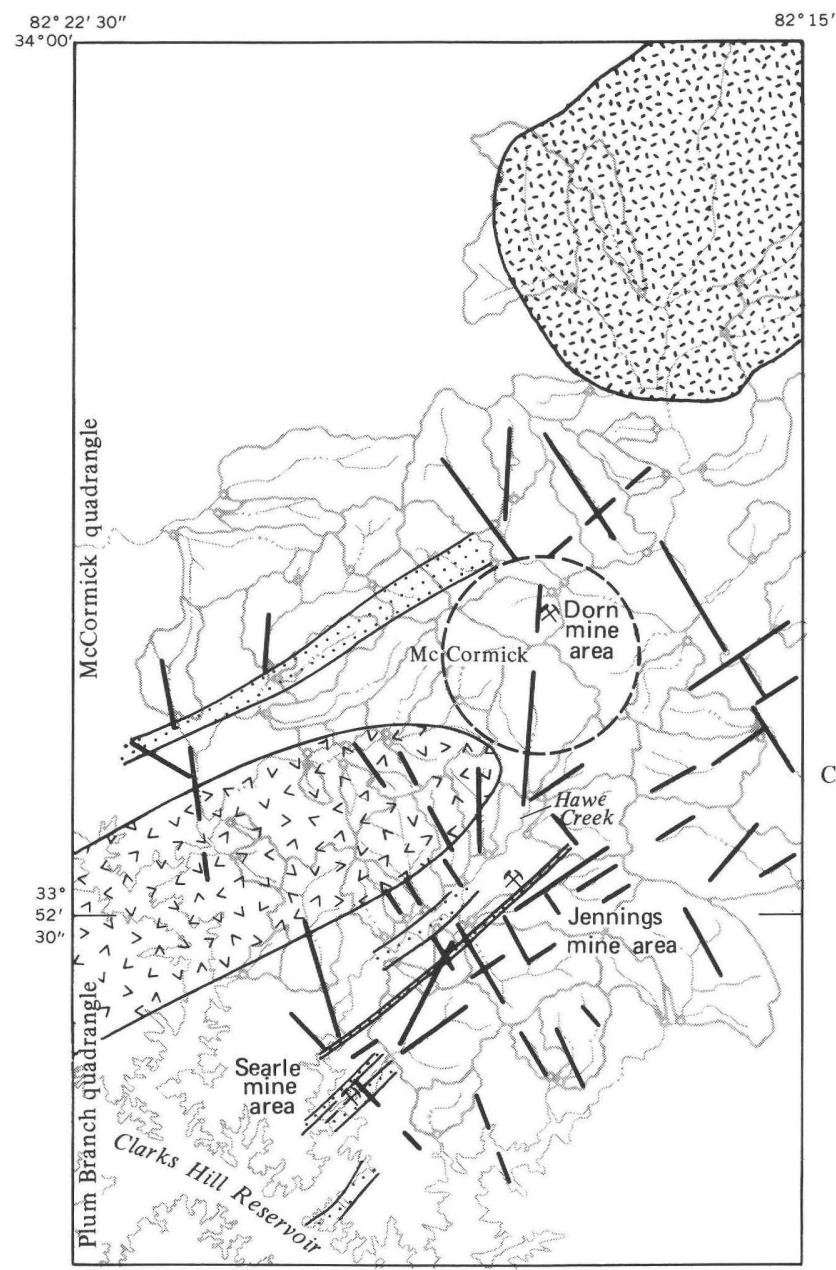

\section{EXPLANATION}

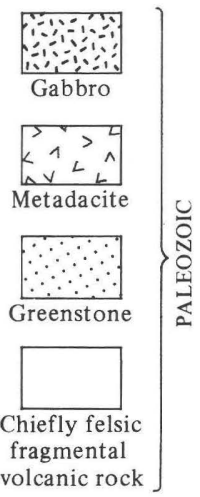

$\overline{\text { Contact }}$

Conspicuously alined stream segment indicating trend of fault, joint, bedding, or cleavage

\section{$x$ \\ Mining area}

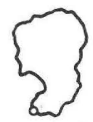

Small-stream drainage basin and sample site

FIGURE 4.-Reconnaissance geologic map of the McCormick and Plum Branch quadrangles showing small-stream drainage basins. 


\section{SAMPLING, ANALYTICAL, AND DATA-PROCESSING PROCEDURES}

Two types of samples were collected in the McCormick area: alluvium from streams and rock or saprolite from roadsides, prospect pits, and mines. All samples were analyzed by a six-step spectrographic method and by colorimetric and atomic absorption methods at laboratories of the U.S. Geological Survey in Denver, Colo., and in mobile field laboratories. Data were processed by computer.

\section{STREAM ALLUVIUM SAMPLES}

Alluvium was collected from 59 small streams (fig. 4). Such alluvium is widely used in geochemical prospecting because it represents material carried to the sample site from within the drainage basin. In McCormick County, streams having a drainage basin of about 0.5 to about 2 square miles each were sampled. Two contrasting types of alluvium were collected from each drainage basin, fine alluvium and coarse alluvium. A heavy mineral concentrate was panned from the coarse alluvium.

The fine alluvium, predominantly silt and clay, was analyzed principally for metal ions derived from soluble or easily weathered minerals, but also for very finely divided but poorly soluble detrital minerals. Such material was dug from alluvium submerged in the beds of the present channels of streams. A few samples, however, are of alluvial clay or silt in the banks at or slightly above the low water level of the streams. Several samples are from the beds of dry streams. Each sample, however, was selected to contain only material brought to the site by the water of the stream being sampled. The samples were collected upstream from major flood plains. The minus 80 -mesh fraction of the samples was analyzed by colorimetric and atomic absorption methods for nickel, copper, molybdenum, cobalt, zinc, silver, and gold and by the six-step spectrographic method for 30 elements. Tables 2 and 3 summarize the results of these analyses. Nickel was below the limit of determination by the colorimetric method.

TABLE 2.-Summary of colorimetric and atomic absorption analyses of fine alluvium from small streams, McCormick County, S. C.

[Analysts: R. Hanson, T. Roemer, A. Toevs, A. Meiers, H. King, J. Frisken, Z. Stephenson, S. Rickard. Constituents in parts per million]

\begin{tabular}{|c|c|c|c|c|c|c|}
\hline & & $\begin{array}{l}\text { Lower } \\
\text { limit of } \\
\text { determination }\end{array}$ & $\begin{array}{c}\text { Geometric } \\
\text { mean }\end{array}$ & $\begin{array}{c}\text { Geometric mean } \\
\times \text { geometric } \\
\text { deviation }\end{array}$ & Maximum & $\begin{array}{c}\text { Number of } \\
\text { analytical } \\
\text { values }\end{array}$ \\
\hline $\begin{array}{l}\mathbf{C u}^{1} \\
\mathbf{Z n}^{2} \\
\mathbf{M o}^{3} \\
\mathbf{C o}^{1} \\
\mathbf{A g}^{3} \\
\mathbf{A u}^{4}\end{array}$ & (1) & $\begin{array}{r}10 \\
25 \\
4 \\
10 \\
.1 \\
.1\end{array}$ & $\begin{array}{r}20 \\
42 \\
5 \\
20 \\
.2 \\
.1\end{array}$ & $\begin{array}{l}70 \\
50 \\
7 \\
30 \\
\quad .3 \\
.15\end{array}$ & $\begin{array}{r}750 \\
100 \\
8 \\
150 \\
.3 \\
.2\end{array}$ & $\begin{array}{r}50 \\
27 \\
3 \\
47 \\
10 \\
8\end{array}$ \\
\hline
\end{tabular}

${ }^{1}$ Colorimetric method.

${ }^{2}$ Atomic absorption method.

${ }^{3}$ Lower limit of determination used as geochemical threshold.

${ }^{4} 10$-gram cold extraction method. 
In addition to the fine alluvium at each of the stream sites, a sample of coarse alluvium or gravel was collected, and a heavy-mineral concentrate was made on the site by panning with a standard 16-inch goldminer's pan (Mertie, 1954; Theobald, 1957; Bell and Overstreet, 1960). Collection procedures were standardized-designed to reduce the factors which might cause variations among the concentrates. The factors standardized were hydraulic conditions at the sample site, volume of sample, and the grain size of the alluvium. At each sample site, 10 quarts of coarse alluvium weighing about 40 pounds was collected. The weight of the heavy-mineral concentrates panned from this volume of material varied from site to site. A summary is given in the table below.

$\begin{array}{ccc}\text { Weight of heavy-mineral concentrates (grams) } \\ \text { Minimum } & \text { Mean } & \text { Maximum } \\ 2.3 & 17.4 & 402.5\end{array}$

The variation in weight of the heavy-mineral concentrates reflects the actual abundance of heavy minerals in the coarse alluvium. The highly magnetic fraction of the heavy-mineral concentrate was removed by hand magnet. The magnetic fraction, although consisting predominantly of magnetite, probably also includes minor amounts of ilmenite or other minerals intergrown with magnetite, grains of other minerals attached to magnetite, and secondary magnetic iron oxides. The range of weight of the magnetic fraction in the heavymineral concentrates is shown in the following table:

\begin{tabular}{cccc}
\multicolumn{4}{c}{ Magnetic fraction of heavy-mineral concentrates (grams) } \\
\multicolumn{4}{c}{ Geometric mean $\times$} \\
Minimum & Geometric mean & geometric deviation & Maximum \\
$<0.1$ & 1.4 & 4.8 & 18.9
\end{tabular}

The nonmagnetic fraction was analyzed by spectrographic methods for 30 elements. The results are summarized in table 4 .

While still in the gold pan, each heavy-mineral concentrate was carefully examined for particles of gold. Particles of gold were identified in the panned concentrates at 13 sample sites. Spectrographic analysis may fail to detect small numbers of gold particles that are easily identified in the gold pan because of the nature of particulate matter, the random distribution of particles, and the low probability that a particle of gold will be included in the small amount of material analyzed. Chemical analysis, which has a lower limit of determination, is more likely to detect silt- or clay-sized gold particles uniformly distributed throughout the fine alluvium. No attempt was made to dig through several feet of alluvium to the bedrock surface nor to take 
TABLE 3.-Summary of spectrographic analyses of 59 fine alluvium samples from small streams, McCormick County, S. C.

[Analyst: D. F. Siems]

\begin{tabular}{|c|c|c|c|c|}
\hline & $\begin{array}{c}\text { Lower } \\
\text { limit of } \\
\text { determination }^{1}\end{array}$ & $\begin{array}{c}\text { Geometric } \\
\text { mean }\end{array}$ & $\begin{array}{c}\text { Geometric mean } \\
\times \text { geometric } \\
\text { deviation }\end{array}$ & Maximum \\
\hline \multicolumn{5}{|c|}{ Percent $^{2}$} \\
\hline $\begin{array}{l}\mathbf{F e} \\
\mathbf{M g}\end{array}$ & $\begin{array}{l}0.05 \\
.02 \\
.05 \\
.002 \\
\end{array}$ & $\begin{array}{l}1.5 \\
.15 \\
.3 \\
.5 \\
\end{array}$ & $\begin{array}{l}3 \\
.5 \\
.7 \\
.7 \\
\end{array}$ & $\begin{array}{l}7 \\
2 \\
2 \\
1 \\
\end{array}$ \\
\hline \multicolumn{5}{|c|}{ Parts per million } \\
\hline 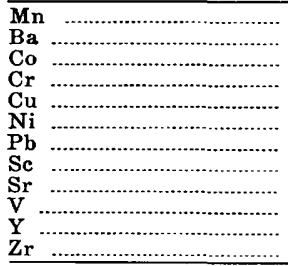 & $\begin{array}{r}10 \\
20 \\
5 \\
10 \\
5 \\
5 \\
10 \\
5 \\
100 \\
10 \\
10 \\
10 \\
\end{array}$ & $\begin{array}{r}700 \\
200 \\
7 \\
20 \\
10 \\
15 \\
10 \\
15 \\
70 \\
70 \\
15 \\
150 \\
\end{array}$ & $\begin{array}{r}\mathbf{1 , 5 0 0} \\
\mathbf{5 0 0} \\
15 \\
70 \\
20 \\
30 \\
20 \\
20 \\
150 \\
150 \\
20 \\
200 \\
\end{array}$ & $\begin{array}{r}5,000 \\
1,500 \\
100 \\
300 \\
50 \\
150 \\
50 \\
20 \\
300 \\
200 \\
50 \\
300 \\
\end{array}$ \\
\hline
\end{tabular}

Elements for which there is an insufficient number of analytical values for statistical analysis

\begin{tabular}{|c|c|c|c|}
\hline & $\begin{array}{l}\text { Lower limit of } \\
\text { determination }\end{array}$ & Maximum & $\begin{array}{c}\text { Number of } \\
\text { analytical values }\end{array}$ \\
\hline \multicolumn{4}{|c|}{ Parts per million } \\
\hline $\begin{array}{l}\mathrm{B}^{3} \\
\mathrm{La}^{4} \\
\text { Mo }\end{array}$ & $\begin{array}{r}10 \\
20 \\
5\end{array}$ & $\begin{array}{r}300 \\
100 \\
7\end{array}$ & $\begin{array}{l}\mathbf{5} \\
\mathbf{5} \\
\mathbf{2}\end{array}$ \\
\hline
\end{tabular}

${ }^{1}$ Approximate visual lower limits of determination for elements analyzed by the six-step spectrographic method.

${ }^{2}$ Results are reported to the nearest number in the series $1,0.7,0.5,0.3,0.2,0.15,0.1$, etc.

${ }^{3}$ Forty-five analyses contain the lowest determinable value and nine analyses contain less than the limit of determination.

${ }^{4}$ Three analyses contain the lowest determinable value and 11 analyses contain less than the limit of determination.

large volumes of material as would have been required for conventional gold placer sampling procedures. By conventional placer sampling procedures and with larger samples, additional streams with gold-bearing alluvium might be found.

\section{ROCK AND SAPROLITE SAMPLES}

Samples of rock and saprolite were collected at intervals of 5-50 feet along two roads near the Jennings mine (fig. 5) and were analyzed by the same methods as the stream-sediment samples (see table 5). The traverses were chosen to intersect possible extensions of the mineralized rock cropping out along the ridge on which the Jennings mine is located. At places where evidence of mineralization appeared in the saprolite, continuous channel samples were collected. The results indicate that three possible mineralized zones were crossed by the traverses (fig. 6). The highway traverse (fig. 6, $C-C^{\prime}$ ) revealed two mineralized zones: 30 feet of rock averaging about $0.16 \mathrm{ppm}$ gold and 34 feet averaging about $0.19 \mathrm{ppm}$ gold. A short soil-sampling 
TABLE 4.-Summary of spectrographic analyses of 56 heavy-mineral concentrates from small streams, McCormick County, S. C.

[Analyst: J. Finley. Results are reported to the nearest number in the series $1,0.7,0.5,0.3,0.2,0.15,0.1$, etc. $]$

\begin{tabular}{|c|c|c|c|c|}
\hline \multicolumn{5}{|c|}{ Percent } \\
\hline & $\begin{array}{c}\text { Lower } \\
\text { limit of } \\
\text { determination }^{1}\end{array}$ & $\begin{array}{c}\text { Geometric } \\
\text { mean }\end{array}$ & $\begin{array}{c}\text { Geometric mean } \\
\times \text { geometric } \\
\text { deviation }\end{array}$ & Maximum \\
\hline $\begin{array}{l}\text { Fe } \\
\text { Mg } \\
\text { Ca } \\
\text { Ti }\end{array}$ & $\begin{array}{l}0.05 \\
.02 \\
.05 \\
.002 \\
\end{array}$ & $\begin{array}{l}7 \\
2 \\
3 \\
\end{array}$ & $\begin{array}{r}10 \\
1 \\
5 \\
7 \\
\end{array}$ & $\begin{array}{r}>10 \\
5 \\
7 \\
>10 \\
\end{array}$ \\
\hline \multicolumn{5}{|c|}{ Parts per million } \\
\hline $\begin{array}{l}\mathrm{Mn} \\
\mathrm{Ba} \\
\mathrm{Co} \\
\mathrm{Cr} \\
\mathrm{Cu} \\
\mathbf{L a}\end{array}$ & $\begin{array}{r}10 \\
20 \\
5 \\
5 \\
5 \\
20 \\
10 \\
5 \\
10 \\
10 \\
100 \\
10 \\
10 \\
10 \\
\end{array}$ & $\begin{array}{r}3,000 \\
70 \\
15 \\
150 \\
70 \\
100 \\
20 \\
10 \\
50 \\
50 \\
100 \\
200 \\
100 \\
500 \\
\end{array}$ & $\begin{array}{r}7,000 \\
150 \\
20 \\
300 \\
100 \\
300 \\
50 \\
20 \\
100 \\
150 \\
200 \\
300 \\
200 \\
1,000 \\
\end{array}$ & $\begin{array}{r}15,000 \\
2,000 \\
100 \\
1,000 \\
200 \\
700 \\
70 \\
100 \\
500 \\
700 \\
500 \\
700 \\
300 \\
2,000 \\
\end{array}$ \\
\hline
\end{tabular}

Elements for which there is an insufficient number of analytical values for statistical analysis

\begin{tabular}{|c|c|c|c|}
\hline & $\begin{array}{l}\text { Lower limit of } \\
\text { determination }\end{array}$ & Maximum & $\begin{array}{c}\text { Number of } \\
\text { analytical values }\end{array}$ \\
\hline \multicolumn{4}{|c|}{ Parts per million } \\
\hline 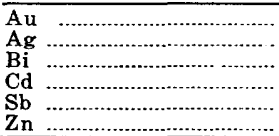 & $\begin{array}{c}10 \\
0.5 \\
10 \\
20 \\
100 \\
200\end{array}$ & $\begin{array}{r}30 \\
7 \\
20 \\
70 \\
300 \\
10,000\end{array}$ & $\begin{array}{l}1 \\
3 \\
1 \\
9 \\
7 \\
6\end{array}$ \\
\hline
\end{tabular}

${ }^{1}$ Approximate visual lower limits of determination for elements analyzed by the six-step spectrographic method.

traverse, (traverse $A-A^{\prime}$, fig. 5), indicated the presence of $0.02 \mathrm{ppm}$ gold and some copper.

Four diamond drill holes spaced at intervals along the ridge on which the Jennings mine is situated were drilled to intersect the mineralized rock at depth. The drill cores from three of the holes have been analyzed by the same methods as the samples from road traverses and streams. The results of analyses of 210 samples of drill core are also summarized in table 5. Sections of the drill core that are orebearing or heavily mineralized have not been included in the analytical results summarized in table 5 in order that statistical calculations performed on saprolite and unweathered rock may be more nearly comparable.

\section{DATA PROCESSING}

The analytical results have been processed by the U.S. Geological Survey's IBM 360/65 computer to obtain statistical parameters, to make correlations which can be used to choose geochemical threshold values, and to evaluate stream drainage basins for mineralized ground. 


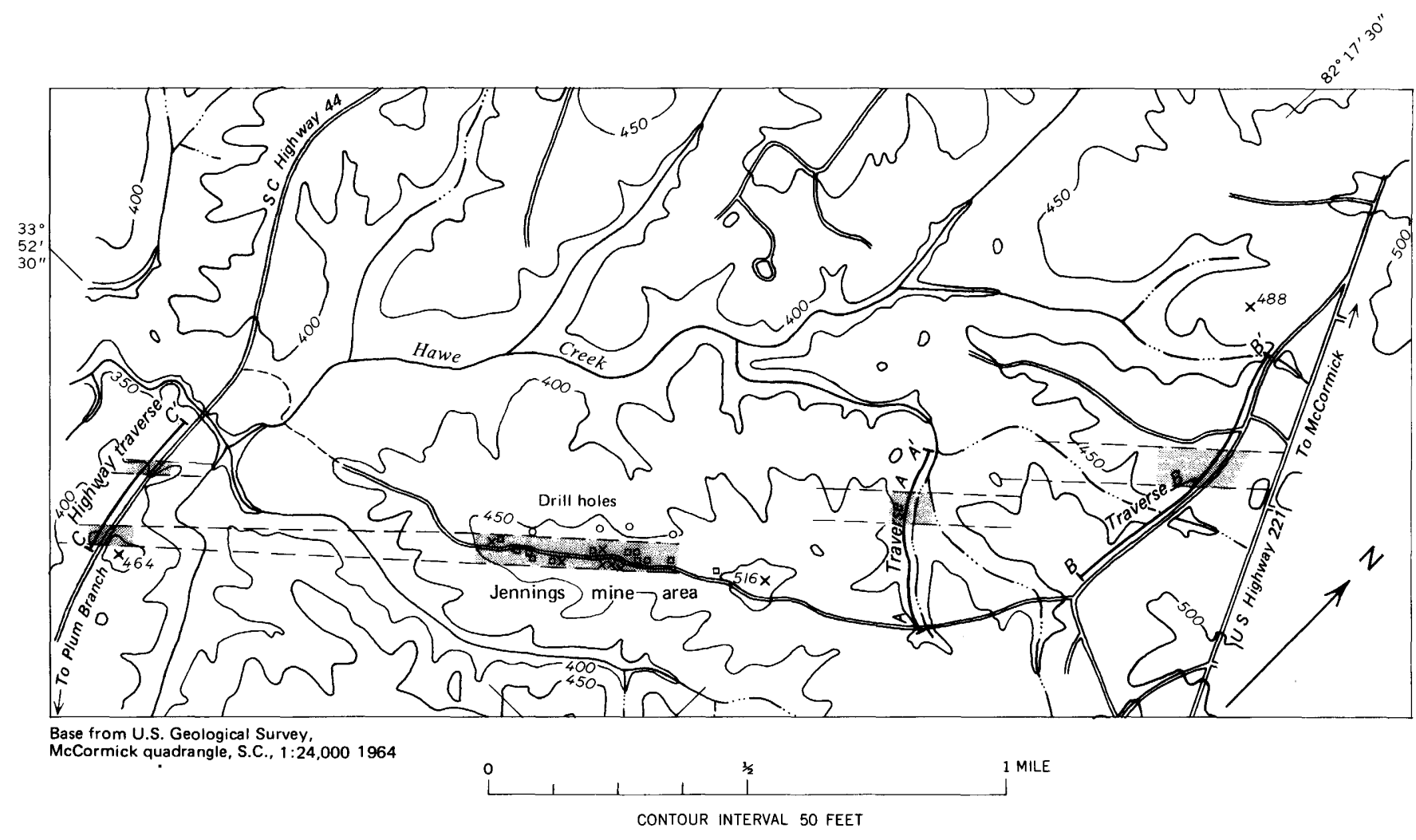

FigURE 5.-Location of saprolite- and soil-sampling traverses and mineralized zones (patterned) and their probable extensions near the Jennings mine, McCormick County, S.C. Base from U.S. Geological Survey, McCormick 71/2minute quadrangle, 1964. 
TABLE 5.-Summary of spectrographic analyses of saprolite and drill core from the vicinity of the Jennings mine, McCormick County, S. C.

[See figure 5 for locations]

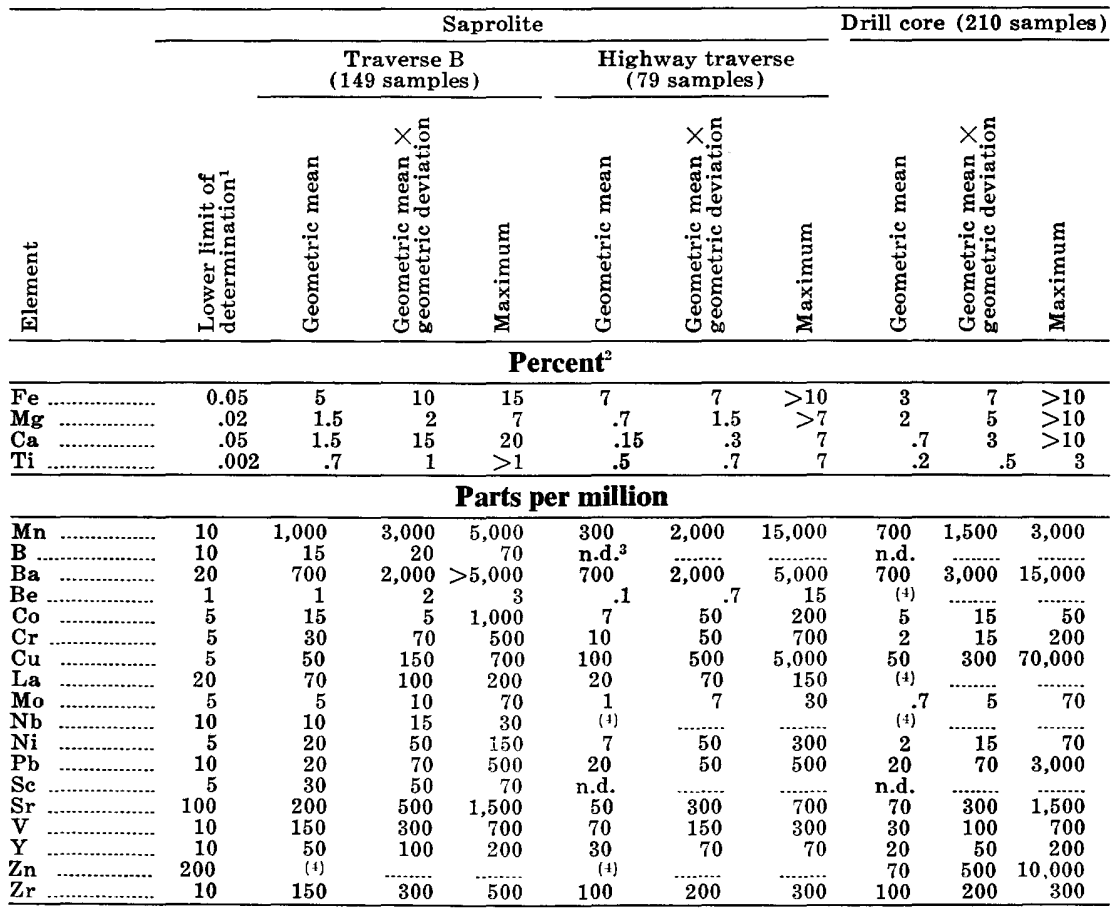

Elements for which there is an insufficient number of analytical values for statistical analysis

\begin{tabular}{|c|c|c|c|c|c|c|c|}
\hline 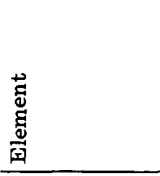 & 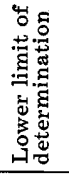 & 胥 & 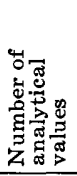 & 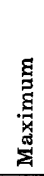 & 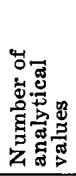 & 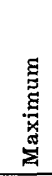 & 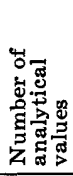 \\
\hline \multicolumn{8}{|c|}{ Parts per million } \\
\hline $\begin{array}{l}\mathrm{Ag} \\
\mathrm{Be}\end{array}$ & $\begin{array}{c}0.5 \\
1 \\
10 \\
20 \\
10 \\
200 \\
\end{array}$ & $\begin{array}{c}1 \\
\ldots \ldots . . \\
\ldots \ldots \\
100 \\
700\end{array}$ & \begin{tabular}{r|}
16 \\
$\cdots$ \\
$\cdots$ \\
$\cdots$ \\
130 \\
\end{tabular} & $\begin{array}{c}<1 \\
\cdots 50 \\
\ldots \ldots \\
700 \\
700\end{array}$ & $\begin{array}{r}1 \\
\cdots \\
5 \\
4 \\
4 \\
\end{array}$ & $\begin{array}{r}\mathbf{5 0} \\
\mathbf{2} \\
\mathbf{1 5} \\
70 \\
\ldots \ldots . . \\
\ldots . .\end{array}$ & \begin{tabular}{r}
22 \\
3 \\
3 \\
16 \\
\hdashline$\ldots .$. \\
\end{tabular} \\
\hline
\end{tabular}

${ }^{1}$ Approximate visual lower limits of determinations for the elements analyzed by the six-step spectrographic method.

${ }^{2}$ Results are reported to the nearest number in the series $1,0.7,0.5,0.3,0.2,0.15,0.1$, etc.

${ }^{3}$ Not determined.

4 Not detected or all samples below the limit of determination.

The computer program, written by Robert Terrazas, U.S. Geological Survey, uses a logarithmic rather than an arithmetic scale and calculates the geometric mean and geometric deviation. All the analytical methods used to test the samples have a lower limit of determination for each element and an optimum range of determination. Values above and below the optimum range are commonly qualified as 


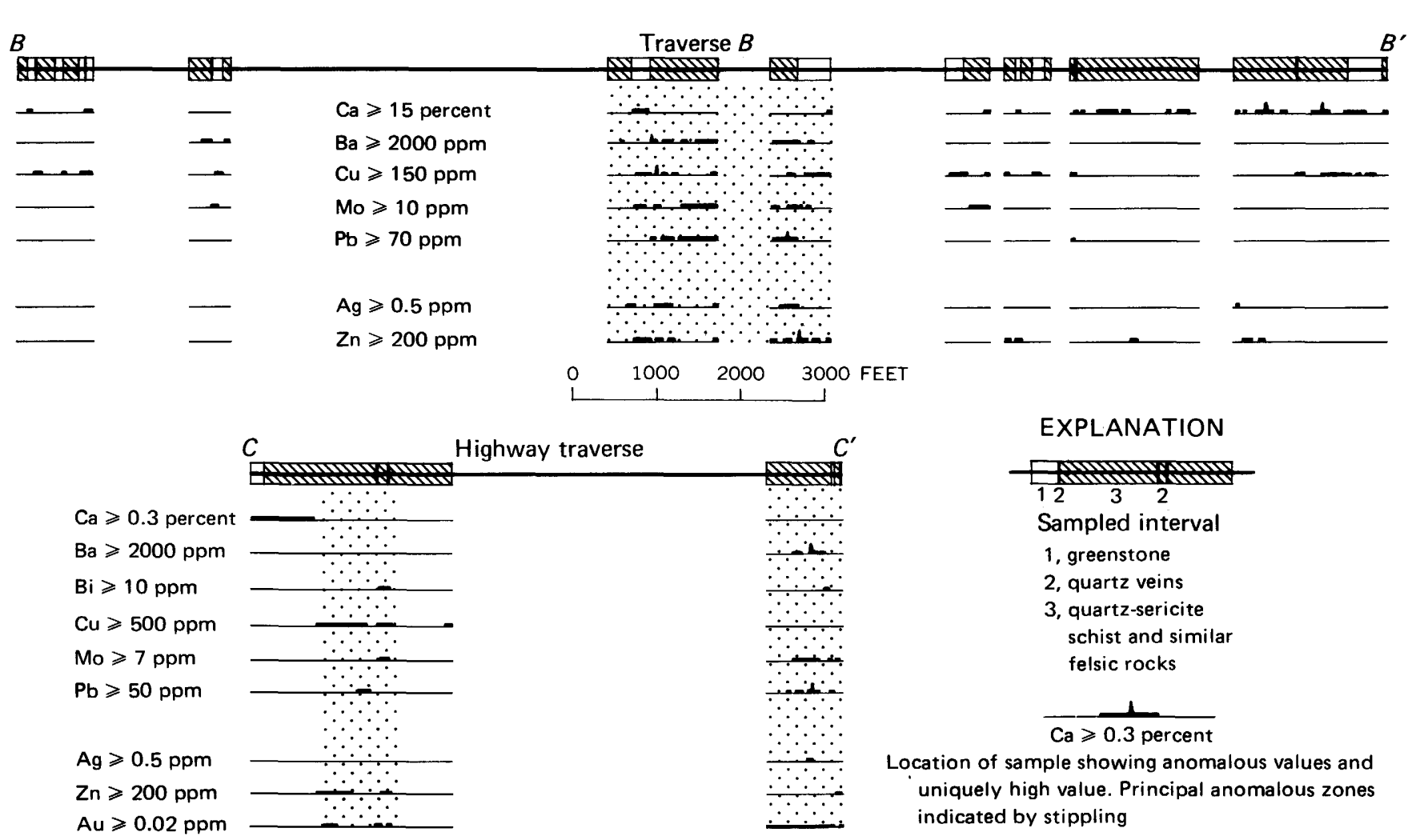

FIGURE 6.-Distribution of anomalous metal values in samples from road traverses shown in figure 5. 
greater than $(>)$, less than $(<)$, or trace. The computations of the geometric mean and the geometric deviation were made using unqualified values above the limit of determination. The distribution of analytical results for many elements is cut off or "censored" at the lower limit of determination. The geometric mean and deviation have been adjusted for these censored distributions, and the values are reported as "less than" or "trace" where they occur. This procedure is from Cohen $(1959,1961)$ and is discussed by Miesch (1967). The results of analysis for some elements contain values qualified as "greater than." The statistical parameters for these elements have been calculated using only unqualified values. The lower limits of determination, geometric mean, and geometric mean multiplied by the geometric deviation are shown in tables $3-5$.

\section{GEOCHEMICAL THRESHOLD}

The geochemical threshold for an element is defined by Hawkes (1957, p. 233) as the limiting anomalous value below which variations represent only normal background effects and above which they have significance in terms of possible mineral deposits. Analytical values above the geochemical threshold are called anomalous. The threshold value for a given element varies for each rock type, and a single value may be too high for some rock types and too low for others. Nevertheless, for this study the geometric mean times the geometric deviation has been chosen as the geochemical threshold; as a result about 68 percent of the samples are below the geochemical threshold and 32 percent are anomalous.

\section{DISTRIBUTION OF ANOMALOUS DRAINAGE BASINS}

The stream-sampling data have been used to prepare maps that show the drainage basins that have threshold or greater amounts of each element and some detrital minerals. The threshold value used is the geometric mean times the geometric deviation that is shown in tables 2-4. Plate $1 A-V$ shows small drainage basins in which fine alluvium contains threshold or greater amounts of one or another of the elements that are given in tables 2 and 3. Plate 2 shows small-stream drainage basins that have heavy-mineral concentrates containing particles of gold detected in the gold pan; those basins in which heavymineral concentrates contain a magnetic fraction weighing 4.8 grams or more are shown on plate 3 . Plate $4 A-Q$ shows small-stream drainage basins with threshold or greater amounts of one or another of the elements in the nonmagnetic fraction that were determined by spectrographic analysis.

\section{CORRELATION AMONG THE ELEMENTS}

The large quantities of data produced by spectrographic analyses make it difficult to recognize and separate in the raw data the associa- 
tions of elements useful as indicators of possible ore deposits from associations due to chance alone. However, various statistical methods are available which help to judge the degree of correlation among the elements. For this report Kendall's correlation coefficient $(\gamma)$, as described by Siegel (1956), was chosen. This correlation coefficient is a nonparametric statistic not dependent on an assumed distribution of analytical values in the original data. The relative concentration of any two elements in the drill core may or may not be associated, and the concentrations may vary directly or inversely. Kendall's correlation coefficient is a measure of these relationships. Associated elements that vary directly have a positive correlation coefficient; those that vary inversely have a negative correlation coefficient. The values for perfect correlation are 1 or -1 , and 0 indicates no correlation. Kendall's correlation coefficient can be tested for statistical significance. Table 6 shows Kendall's correlation coefficients for twenty elements in the drill core from the Jennings mine area. Silver $(\mathrm{Ag})$ is shown to be associated with calcium $(\mathrm{Ca})$ and to have a correlation coefficient of 0.40 . This correlation is statistically significant at a probability level of $0.05(\alpha=0.05)$. This association of silver and calcium is probably not due to chance alone. Likewise, table 6 shows that chromium and silver are associated. They have a negative correlation coefficient of -0.49 which is statistically significant at a probability level of 0.01 $(\alpha=0.01)$. Here inverse association of silver and chromium is unlikely to be due to chance. Thus table 6 shows that any association of silver with the other elements is not statistically significant at the level of probability chosen; instead the association is most likely due to chance alone.

\section{CONCLUSIONS}

The distribution of stream basins containing alluvium with anomalous amounts of elements and detrital minerals indicates that base metals and gold are widespread in the McCormick area. Most such basins are in areas underlain by felsic fragmental volcanic rock and interlayered greenstone and are absent in areas underlain by the metadacite.

The small-stream basins that provide the most favorable indications of ore-bearing rock have been evaluated by a scheme using the correlation coefficients of table 6 as a guide. Table 6 shows that in the drill core from the Jennings mine area, gold is positively correlated with copper and barium. Therefore, stream basins which contain goldbearing alluvium and anomalous barium or copper or both are evaluated as more favorable areas for gold than stream basins with only gold-bearing alluvium. In table 6 magnesium has a negative correlation coefficient with gold. Anomalous magnesium in stream alluvium is considered a negative factor; therefore, the favorability of a basin 
TABLE 6.-Kendall's correlation coefficients for drill core analyses in the Jennings mine area, McCormick County, S. C.

[If no entry shown, correlation not significant at $\alpha=0.05$; asterisk indicates correlations probably significant

\begin{tabular}{|c|c|c|c|c|c|c|c|c|c|c|c|c|c|c|c|c|c|c|c|c|}
\hline $\mathrm{Mg}$ & $\mathrm{Ca}$ & $\mathrm{Ti}$ & $\mathrm{Mn}$ & $\mathrm{Ag}$ & $\mathrm{Ba}$ & Co & $\mathrm{Cr}$ & $\mathrm{Cu}$ & $\mathrm{La}$ & Mo & $\mathrm{Ni}$ & $\mathrm{Pb}$ & $\mathrm{Sr}$ & $\mathrm{V}$ & $\mathbf{Y}$ & $\mathrm{Zr}$ & $\mathrm{Zn}_{\mathrm{n}}$ & $\mathrm{Au}$ & As & \\
\hline \multirow[t]{20}{*}{.21} & .33 & .44 & .30 & & & .55 & .36 & .34 & & & .25 & $.12^{*}$ & .38 & .62 & & $-.11^{*}$ & & & & $\mathrm{Fe}$ \\
\hline & & .26 & .45 & & -.15 & .22 & .19 & .13 & & & .39 & .15 & & .27 & & $-.11^{*}$ & .39 & -.52 & -.15 & $\mathbf{M g}_{\mathbf{g}}$ \\
\hline & & & .19 & $.40^{*}$ & .18 & .31 & .22 & & & $-.19 *$ & .38 & $-.11^{*}$ & .66 & .57 & .25 & .17 & -.31 & & & $\mathrm{Ca}$ \\
\hline & & & .23 & & $-.10^{*}$ & .30 & .19 & & & -.25 & .39 & & .54 & .66 & .38 & .25 & & & & $\mathrm{Ti}$ \\
\hline & & & & & -.19 & .25 & .21 & $.11^{*}$ & & & .32 & & .23 & .32 & & $-.09 *$ & .18 & & & Mn \\
\hline & & & & & & & -.49 & & & & & & & & & & & & & As \\
\hline & & & & & & -.33 & -.17 & $.11 *$ & & & .40 & & -.17 & -.14 & & & & $.32 *$ & .20 & $\mathrm{Ba}$ \\
\hline & & & & & & & .40 & .20 & & & .54 & $.12^{*}$ & .42 & .57 & & & $-.14^{*}$ & & & Co \\
\hline & & & & & & & & .15 & & & .60 & .22 & .34 & .45 & & & & & & $\mathrm{Cr}$ \\
\hline & & & & & & & & & & .25 & & .15 & & .18 & -.18 & -.28 & & $.45^{*}$ & & $\mathrm{Cu}$ \\
\hline & & & & & & & & & & & & -.68 & & & & $.41^{*}$ & & & -.80 & La \\
\hline & & & & & & & & & & & $-.29^{*}$ & $.24^{*}$ & & & -.31 & -.29 & & & $.24^{*}$ & Mo \\
\hline & & & & & & & & & & & & & .46 & .62 & & & & & & $\mathrm{Ni}$ \\
\hline & & & & & & & & & & & & & & & & & .24 & & $.13^{*}$ & $\mathbf{P b}$ \\
\hline & & & & & & & & & & & & & & .59 & .20 & .17 & -.33 & & & $\mathrm{Sr}$ \\
\hline & & & & & & & & & & & & & & & & & -.16 & & & $\mathrm{v}$ \\
\hline & & & & & & & & & & & & & & & & .66 & & & & $\mathbf{Y}$ \\
\hline & & & & & & & & & & & & & & & & & -.17 & & & $\mathrm{Zr}$ \\
\hline & & & & & & & & & & & & & & & & & & & & $\mathrm{z}_{\mathrm{n}}$ \\
\hline & & & & & & & & & & & & & & & & & & & & $\mathrm{Au}$ \\
\hline
\end{tabular}


as an area containing gold deposits is reduced. The scheme for evaluating each stream basin for the elements gold, copper, zinc, lead, and manganese in turn is illustrated below for gold. In this scheme, a

Scheme for selecting small-stream drainage basins

that provide most favorable indication of underlying gold-bearing rock in the McCormick area, South Carolina

\begin{tabular}{|c|c|c|c|c|c|c|c|c|c|c|}
\hline \multirow{3}{*}{\multicolumn{2}{|c|}{$\begin{array}{c}\text { Stream } \\
\text { drainage } \\
\text { basin }\end{array}$}} & \multicolumn{4}{|c|}{$\begin{array}{c}\text { Elements present in anomalous } \\
\text { amounts/unit volume in } \\
\text { heavy-mineral concentrates }\end{array}$} & \multicolumn{4}{|c|}{$\begin{array}{l}\text { Elements present in anomalous } \\
\text { amounts/unit volume in } \\
\text { fine alluvium }\end{array}$} & \multirow{3}{*}{$\begin{array}{l}\text { Total factors } \\
\text { (positive- } \\
\text { negative) }\end{array}$} \\
\hline & & \multirow[b]{2}{*}{$\mathrm{Au}$} & \multicolumn{2}{|c|}{$\begin{array}{l}\text { Positive } \\
\text { factors }\end{array}$} & \multirow{2}{*}{$\begin{array}{c}\begin{array}{c}\text { Negative } \\
\text { factors }\end{array} \\
\mathrm{Mg}^{2}\end{array}$} & & \multicolumn{2}{|c|}{$\begin{array}{l}\text { Positive } \\
\text { factors }\end{array}$} & \multirow{2}{*}{$\begin{array}{c}\begin{array}{c}\text { Negative } \\
\text { factors }\end{array} \\
\mathrm{Mg}^{2}\end{array}$} & \\
\hline & & & $\mathbf{C u}^{1}$ & $\mathrm{Ba}^{1}$ & & $\mathrm{Au}$ & $\mathrm{Cu}^{1}$ & $\mathbf{B} \mathbf{a}^{1}$ & & \\
\hline $\mathbf{a}$ & ................... & .......... & $x$ & $\bar{x}$ & ......... & $\bar{x}$ & $\bar{x}$ & $\ldots$ & $\bar{x}$ & 3 \\
\hline b & ...................... & $x$ & $x$ & $x$ & $x$ & $x$ & $x$ & $x$ & $x$ & 4 \\
\hline c & . & $x$ & & & $x$ & & $x$ & & & 1 \\
\hline $\mathbf{x}$ & .................. & ....... & $x$ & $x$ & $x$ & $x$ & $x$ & ........... & $x$ & 2 \\
\hline & .................... & $x$ & $x$ & $x$ & .......... & $x$ & $x$ & $x$ & $x$ & 5 \\
\hline & …………......... & $x$ & $x$ & $x$ & ......... & $x$ & $x$ & $x$ & .......... & 6 \\
\hline
\end{tabular}

${ }^{1}$ Element with positive Kendall correlation coefficient with gold in drill core (table 6 ).

${ }^{2}$ Element with negative Kendall correlation coefficient with gold in drill core (table 6 ).

value of 1 is assigned to gold and to each element with a positive correlation coefficient (copper and barium) and a value of -1 to each element with a negative correlation (magnesium). Plate $5 A$ shows the stream basins in which the algebraic sum of these factors is 2 or more. Plate $5 B-E$ show stream basins that have been evaluated in a similar way for copper, zinc, lead, and manganese. In each figure stream basins are shown as most favorable only if the factors total 2 or more.

Most of the drainage basins most favorable for the ore elements are in a north-trending zone along Hawe Creek. The basins favorable for copper and gold are the most widely distributed along this zone. Lead and zinc are less widely distributed and closest to the mined areas. Stream basins most favorable for manganese tend to be peripheral to basins favorable for the other ore elements. The arrangement of stream basins favorable for manganese suggests a halo of manganese-rich rocks similar to those noted around copper deposits in Maryland (A. V. Heyl, Jr., written commun. 1971), and in many western districts. Although plate $5 A-E$ shows stream drainage basins instead of mineralized rock, the distribution of the favorable stream basins suggests a mineralized zone. The zone is alined slightly east of north along the upper part of Hawe Creek. This is one of the alined stream segments controlled by a divergent fracture or a fault (fig. 3). In Lieber's description of the Dorn mine workings, then in operation, he included an illustration (Lieber, 1860) which shows (idealized he says), the echelon ore zones offset by a fault (fig. 7). The exact location of the ore zones in the mine is not known, but the old workings are on or are very close to the possible fault zone along 


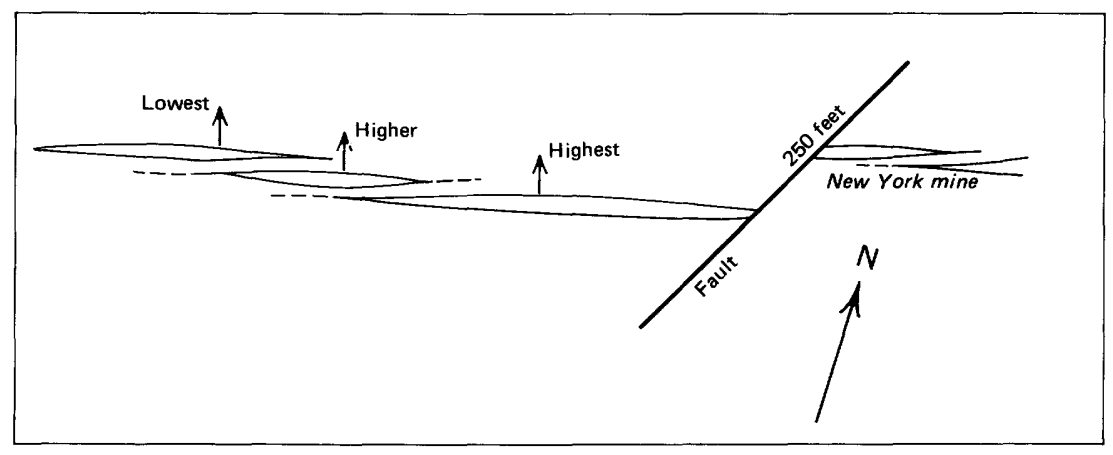

FigURE 7.-Idealized ground plan of the veins at the Dorn mine (from Lieber, 1860).

the upper part of Hawe Creek. The gold-bearing rocks and ore at the Dorn and Jennings mines, as far as known, are very similar, and mining has been largely along strike of the quartz-sericite schist. Lieber's information and the results of sampling along roads (fig. 5) suggest that the mineralized ground at both mines is offset by a fault or a group of faults under the upper part of Hawe Creek. Closely spaced samples along roads east and west of the Jennings mine indicate that the gold-bearing rocks extend along strike at least a mile to west but to the east appear to have been offset to the north. Although a fault that offsets the gold-bearing rocks at the Dorn and Jennings mines may not itself be mineralized, geochemical anomalies suggest that the upper part of Hawe Creek might be mineralized ground. A comparison of Kendall's correlation coefficients for the ore elements and arsenic in felsic fragmental rocks and in greenstones in the drill core from the Jennings mine area (fig. 8) shows more significant correlations between elements in felsic fragmental rocks than in greenstones. Copper, for example, has significant positive correlations with lead, gold, barium, cobalt, and molybdenum in felsic fragmental rocks but not in greenstones. Similarly, lead is positively correlated at a significant level with iron, copper, zinc, arsenic, chromium, and molybdenum in felsic rocks but not in greenstones. These correlations suggest that because the ore elements are more closely associated in the felsic fragmental rocks than in the greenstones, the felsic rocks are a more favorable host.

From Graves Mountain to McCormick a number of geologic features suggest that the mineralization at the various scattered places is related and had a similar history. These features are: the similar host rock; the similarities of the ore at the Dorn mine, the Jennings mine, and the Seminole-Magruder mine; the belt of epigenetic manganese deposits extending from McCormick to Graves Mountain and 


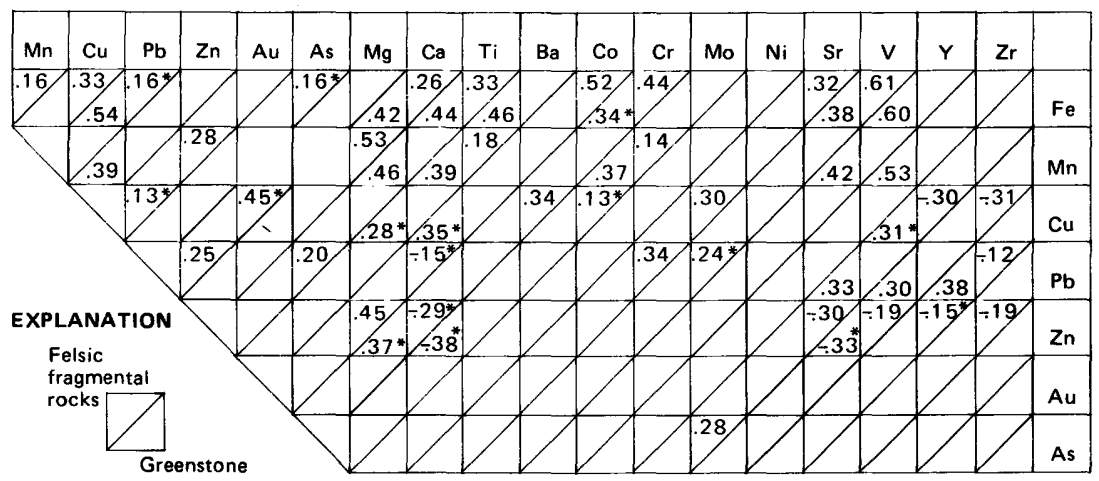

FiguRE 8.-Kendall's correlation coefficients for analyses of felsic fragmental rocks and greenstone in drill core from the Jennings mine area, McCormick County, S.C. If no entry is shown, correlations are not significant at $\alpha=0.05$. Asterisk indicates correlations probably significant at $\alpha=0.05$. All other correlations significant at $\alpha=0.01$.

near the mass of metadacite (fig. 1); the barite in fracture zones in the hydrothermal replacement body on Graves Mountain; noteworthy amounts of barite near the Seminole-Magruder mine, and anomalous amounts of barium in stream alluvium near the Dorn mine.

\section{SUGGESTIONS FOR PROSPECTING}

The results of geochemical sampling indicate that prospecting would be more fruitful along the north-trending zone of stream drainage basins than along the extensions of mine workings. Ore minerals may have been localized by faults along the upper part of Hawe Creek. Pardee and Park (1948, p. 119) questioned the existence of such faults, because they could not find those described by Lieber (1860) in the accessible workings. Nevertheless, the northward (fig. 4) alinement of stream basins containing anomalous concentrations of the ore elements across the strike of foliation of the rocks that have been mined for gold indicates localization of the mineralization by faults or fissures. This north-trending zone seems to be the most favorable area in which to test for sulfide-bearing ore deposits. The positive and negative factors used to outline drainage basins favorable for gold and copper in the McCormick area may prove useful in geochemical exploration elsewhere in the central Savannah River area of Georgia and the slate belt in South Carolina.

\section{REFERENCES}

Bell, Henry, III, and Overstreet, W. C., 1960, Geochemical and heavy-mineral reconnaissance of the Concord quadrangle, Cabarrus County, North Carolina: U.S. Geol. Survey Mineral Inv. Field Studies Map MF-234.

Cohen, A. C., Jr., 1959, Simplified estimators for the normal distribution when samples are singly censored or truncated: Technometrics, v. 1 , no. 3 , p. 217-237. 
1961, Tables for maximum likelihood estimates; singly truncated and singly censored samples: Technometrics, v. 3, no. 4, p. 535-541.

Crawford, T. J., Hurst, V. J., and Ramspott, L. D., 1966, Extrusive volcanics and associated dike swarms in central-east Georgia-Guidebook: Geol. Soc. America, Southeastern Sec., Field Trip 2, 1966, Athens, Ga., Univ. Georgia, Dept. Geology, 53 p.

Crawford, T. J., 1968a, Geologic map of Columbia County, Georgia: Augusta, Ga., Central Savannah River Area Planning and Development Commission and Department Geology, Univ. Georgia, scale 1 inch $=$ about 13/4 miles.

-1968b, Geologic map of Lincoln County, Georgia: Augusta, Ga., Central Savannah River Area Planning and Development Commission and Department Geology, Univ. Georgia, scale 1 inch = about $13 / 4$ miles.

-1968c, Geologic map of McDuffie County, Georgia: Augusta, Ga., Central Savannah River Area Planning and Development Commission and Department Geology, Univ. Georgia, scale 1 inch $=$ about $13 \frac{1}{4}$ miles.

-1968d, Geologic map of Wilkes County, Georgia: Augusta, Ga., Central Savannah River Area Planning and Development Commission and Department Geology, Univ. Georgia, scale 1 inch = about $13 / 4$ miles.

Espenshade, G. H., and Potter, D. B., 1960, Kyanite, sillimanite, and andalusite deposits, southeastern States: U.S. Geol. Survey Prof. Paper 336, 121 p.

Fouts, J. A., 1966, The geology of the Metasville area, Wilkes and Lincoln Counties, Georgia: M.S. thesis, Univ. of Georgia, Athens, Ga.

Hawkes, H. E., 1957, Principles of geochemical prospecting: U.S. Geol. Survey Bull. 1000-F, p. 225-355.

Hurst, V. J., 1959, The geology and mineralogy of Graves Mountain, Georgia: Georgia Geol. Survey Bull. 68, 33 p.

Hurst, V. J., Crawford, T. J., and Sandy, John, 1966, Mineral resources of the Central Savannah River area, v. 1: Washington, D.C., U.S. Econ. Devel. Adm., $467 \mathrm{p}$.

Lieber, O. M., 1860, Report on the survey of South Carolina; being the fourth annual report ... : Columbia, S.C., 194 p.

Mertie, J. B., Jr., 1954, The gold pan; a neglected geological tool: Econ. Geology, v. 49 , no. 6 , p. $639-651$.

Miesch, A. T., 1967, Methods of computation for estimating geochemical abundance: U.S. Geol. Survey Prof. Paper 574-B, 15 p.

Overstreet, W. C., and Bell, Henry, III, 1965a, The crystalline rocks of South Carolina: U.S. Geol. Survey Bull. 1183, 126 p.

1965b, Geologic map of the crystalline rocks of South Carolina: U.S. Geol. Survey Misc. Geol. Inv. Map I-413, scale 1:250,000.

Pardee, J. T., and Park, C. F., Jr., 1948, Gold deposits of the southern Piedmont: U.S. Geol. Survey Prof. Paper 213, 156 p. (including 45 maps in separate case).

Peyton, A. L., and Cofer, H. E., Jr., 1950, Magruder and Chambers copper deposits, Lincoln and Wilkes Counties, Georgia: U.S. Bur. Mines Rept. Inv. RI 4665, $23 \mathrm{p}$.

Shapiro, Leonard, and Brannock, W. W., 1962, Rapid analysis of silicate, carbonate, and phosphate rocks: U.S. Geol. Survey Bull. 1144-A, 56 p.

Siegel, Sidney, 1956, Nonparametric statistics for the behavioral sciences: New York, McGraw-Hill Book Co., 312 p.

Theobald, P. K., Jr., 1957, The gold pan as a quantitative geologic tool: U.S. Geol. Survey Bull. 1071-A, 54 p. 

